\title{
Compliance with International Law: Theoretical Perspectives
}

\author{
Liaquat A. Siddiqui*
}

\section{Introduction}

International law seems to regulate increasingly every aspect of our lives- public and private, as globalization and interdependence are becoming more and more a reality of modern world. In considering the effectiveness of international law, compliance has always been an issue of debate among the international law scholars. Without ensuring a robust compliance mechanism, international law is often reduced to a 'tiger' made of paper having no teeth to bite. 'Implementation' in its simplest form means enacting necessary domestic laws and regulations in order to give effect to a state's international law obligations. But 'compliance' requires something more. It indicates both quantitative and qualitative conformity of a state's behavior to the rules of international law. ${ }^{1}$ Compliance therefore has always been at the center of international law discourse.

However, in order to examine the compliance behavior of states with regard to obligations of international law, it is important to consider the theories on compliance propagated by prominent scholars representing various streams of international law. Theories are not abstract ideas, rather they are based on empirical data such as, reallife conflicts, disputes and case studies. They try to give us a deeper understanding as to why and how international law is created and obeyed. They focus on factors that influence compliance performance of states with regard to international law. These theories help us understand the functioning of international law in a complex world from different perspectives. A proper knowledge of these theories may help us design better international legal order to meet the newer challenges of the world community in future.

Theoretical discussion is important not only to understand the reasons for poor level of compliance by states with obligations of international law, but also to suggest measures to improve the existing compliance behavior of such states. Among the various theories of compliance, only a few have made some considerable efforts to understand and explain the compliance behaviour of states with regard to

\footnotetext{
Professor, Department of Law, University of Dhaka.

1 See, generally for further discussion. Ronald B. Mitchell, 'Compliance Theory: An Overview' in James Cameron, Jacob Werksman and Peter Roderick (eds), Improving Compliance with International Environmental Law (Earthscan 1996); Roger Fisher, Improving Compliance with International Law (University Press of Virginia 1981) 20; Oran R. Young, Compliance and Public Authority: A Theory with International Applications (Johns Hopkins University Press1979) 104. Harold K. Jacobson and Edith B. Weiss, Strengthening Compliance with International Environmental Accords: Preliminary Observations from a Collaborative Project (Brill 1995) 119-148.
} 
international law in general and treaty commitments in particular. ${ }^{2}$ This article therefore reviews the major theories on 'Why do nations obey international law?'. It examines the main arguments of these theories and gives the readers a comparative analysis in order to understand why and how states do comply with international law, from their relevant perspectives.

Due to time and space constraint, this article does not want to discuss traditional theories of compliance ${ }^{3}$. Nor does it want to explore extra-legal theories of compliance available in the literature of other disciplines. ${ }^{4}$ It intends to focus mostly on the major contemporary veins of international legal scholarship which include the managerial school, fairness theory, transnational legal process and reputational theory. These theories underscore the role of international law, with various degrees, in influencing the compliance behavior of states with international law.

\section{Managerial School}

Managerial School, expounded by professor Abram Chayes and Antonia Handler Chayes of Harvard University, puts significant emphasis on the role of array of managerial techniques developed under regulatory treaty regimes in improving the compliance behavior of state parties. ${ }^{5}$ These managerial techniques include information-gathering, reporting requirements, assessment and review of the compliance performance of state parties, monitoring etc. Reporting and information-

2 Teall E. Crossen, Multilateral Environmental Agreements and the Compliance Continuum (Expresso Preprint Series, University of Calgary 2003) 36. See also, 'Symposium on Method in International Law' (1999) 93 The American Journal of International Law 291-423.

3 Traditional Theories such as, International Legal Positivism propagates that states comply with international law because they emanate from the free consent of sovereign states. For further discussion, see, Bruno Simma and Andreas L. Paulus, 'The Relationship of Individuals for Human Rights Abuses in Internal Conflicts: A Positivist View' (1999) 93 The American Journal of International Law303-304. John Austin, The Province of Jurisprudence Determined, etc. (Weidenfeld \& Nicolson 1954) 127. For criticisms of positivist theory, see, Siegfried Wiessner and Andrew R. Willard, 'Policy-Oriented Jurisprudence and Human Rights Abuses in Internal Conflict: Toward a World Public Order of Human Dignity' (1999) 93 American Journal of International Law 316. John K. Setear, 'An Iterative Perspective on Treaties: A Synthesis of International Relations Theory and International Law' (1996) 37(1) Harvard International Law Journal 160.

4 The major international relation theories relevant to compliance issue are Realist, Rationalist, and Constructivist. For example, the realist school of thought developed after the Second World War by Edward Hallett Carr, Hans J Morgenthau, George F. Kennan, and Stanley Hoffmann consider the pursuit and use of power and the anarchic structure of modern international relations as the primary determinant of international behaviour. This school essentially denies the relevance of international law and organisations to 'matters of vital national interest' or of 'high international politics'. To realists, law influences compliance behaviour only if the issue at stake is relatively unimportant, or a non-security matter. They have shown little interest in considering treaties as a source of international behaviour. See for further discussion, Hans J Morgenthau, Politics Among Nations: The Struggle for Power and Peace (revised by K.W. Thompson, McGraw-Hill 2005) 253.

5 See, Abram Chayes and Antonia Handler Chayes, The New Sovereignty (Second Printing, Harvard University Press1998) 22-28. 
gathering techniques help monitor compliance progress and generate mutual confidence by providing transparency in decision-making. ${ }^{6}$ On-site inspection is also used in environmental treaties in order to verify information or compliance performance. The assessment and review process what Chayeses call 'discursive process' help supervisory bodies identify causes of non-compliance or inadequate compliance. ${ }^{7}$

After reviewing various treaty regimes on trade, resource management, security, environment and human rights, Chayeses conclude that states have a propensity to comply with their treaty obligations and that non-compliance is much more the exception than the rule. They have identified three primary factors that contribute to this general propensity to comply. These are: efficiency, interests, and norms. ${ }^{8}$ First, once a treaty regime is up and running, compliance is usually the most efficient choice for states. According to them, states are likely to adhere to the path identified by the treaty regime, rather than spending scarce resources on the continuous recalculation of the costs and benefits of a range of courses of actions. Complex organizations tend to adhere to authoritatively-established routines. Second, states do not form and join regimes lightly. Interest analysis suggests that states only conclude and adopt treaties that they think will best serve their interests. Treaty regimes are institutions in which we can expect the parties to have developed and expressed deeply sunk interests. Third, they emphasise the normative element of the compliance. People often follow the law out of a sense of duty and obligation even without calculating the possibility of punishment. Similarly, on the international level, pacta sunt servanda-'treaties must be observed by their parties in good faith' has the compliance pull. ${ }^{9}$

Given that states have a general propensity to comply, the sources of residual non-compliance according to Chayeses are three: First, ambiguity of obligation which often results in non-compliance. However, they explain that imprecise treaty language is sometimes necessary in order to develop a regime to govern a complex and changing issue area. Second, lack of domestic capacity. Classical treaties entail inter-state obligations, but modern treaty regimes such as environmental treaty regimes require their state parties to address issues deeply related to socio-economic concerns. For example, sustainable development and change in energy policy and practice require a behavioural change of many small or big industries, business enterprises, which are deeply related to various socio-economic aspects of a society. It is possible that even when the political will is present, a state many lack necessary

9 ibid 3-7.
} 
technical, financial or administrative resources to implement their environmental treaty obligations fully. ${ }^{10}$

Since non-compliance is not wilful in most cases, Chayeses argue that a coercive 'enforcement model' for ensuring compliance is inappropriate. They observe that 'enforcement model' is a common pre-occupation of policy makers and scholars. They negate this pre-occupation by asking: Why focus on coercion and punishments when the major concern is not wilful disobedience but rather factors such as ambiguity of obligations and insufficient capacity? ${ }^{11}$

The approach of the Managerial School provides important insights into the causes of non-compliance and emphasizes the need for utilizing managerial techniques to bring a non-compliant state to a compliant situation. Chayeses' Managerial School has comprehensively explored the impact of various managerial techniques on state parties from a legal perspective. They underscore the need for domestic capacity building in improving the compliance behaviour of state parties especially developing country parties. In many areas of international law compliance of developing countries can be significantly improved by technological and financial support from developed countries. Unfortunately developing countries do not possess them. Nor their domestic priorities (fulfilment of basic needs) allow them to spend their scarce resources to resolve the global environmental problems such as, ozone depletion and climate change, created mostly by developed countries. This approach can explain many issues involved in the compliance behaviour of developing countries.

The most popular criticisms of the views of Managerial School are: first, it does not focus on customary international law and second, there is little focus on the internalisation of treaty norms into the domestic legal system of state parties. ${ }^{12}$

\section{Fairness Theory}

Thomas M. Franck, professor of law at New York University, is the proponent of fairness theory ${ }^{13}$. Although Franck's central question is not why do nations obey international law, he argues that a perception that law is fair and therefore it encourages compliance. ${ }^{14}$ Franck's fairness theory contains two components, substantive and procedural. Substantive fairness refers to distributive justice or equity and procedural fairness refers to legitimacy. Although he notes difficulty in defining

\footnotetext{
${ }^{10}$ ibid 9-17.

11 ibid 9-10.

${ }^{12}$ However, Abram Chayes expressed his School's view on customary international law issues. See, 'Implementation, Compliance and Effectiveness' (1997) 91 Proceedings of the Annual Meeting (American Society of International Law) 70.

${ }^{13}$ See, Thomas M. Franck, Fairness in International Law and Institutions (Clarendon Press, 1998).

${ }^{14}$ Harold H. Koh, Why do Nations Obey International Law? 106 Yale L. J., (1997), 2641.
} 
equity, he observes that the allocation among states of scarce resources provides an area where notions of distributive justice are accepted as relevant in international law. ${ }^{15}$ On the other hand, legitimacy refers to that attribute of a rule which conduces to the belief that it is fair because it was made and is applied in accordance with right process. ${ }^{16}$

Franck has developed a four-factor test to determine the legitimacy or the compliance pull of rules on states. These are 'determinacy', 'symbolic validation', 'coherence', and 'adherence'. 'Determinacy' makes a rule's massage clear. ${ }^{17}$ 'Symbolic validation' is procedural ritual for the preparation of substantive rule. ${ }^{18}$ 'Coherence' is the degree of connection between rational principles on the one hand, and a rule on the other. To divide a loaf of bread equally between two persons is a coherent rule, based on the principle of equal distribution. Giving the whole loaf to the person with bushier eyebrows is less coherent, because eyebrow bushiness possesses less generality and rationality as a principle of distribution. ${ }^{19}$ 'Adherence' is the vertical nexus between a primary rule of obligation and a hierarchy of secondary rules identifying the sources of rules and establishing normative standards that define how rules are to be made, interpreted and applied. ${ }^{20}$

Franck has examined the Vienna Ozone Convention, Montreal Protocol and Climate Change Convention and holds that state parties to these treaties have adopted many provisions based on fairness in sharing the cost of remedying the global environmental problems of ozone depletion and climate change. These include a grace period to fulfil the reduction obligation and financial and technical assistance to developing countries. He argues that this is an acknowledgment of lesser-developed countries' fairness claims to exemption, to technology transfer, and to compensatory financing. ${ }^{21}$

He comments, 'the industrial world, which at first rejected all resource transfer, came to realize that it would be both fair, and ultimately, cheaper, for the rich nations to help the poor to adapt to the changes that global ozone layer protection will require of them, ${ }^{22}$ He considers the trade restriction provisions of the Montreal Protocol, which prevent free riding as mechanism for ensuring legitimacy of rules. Although he mentions about 'common but differentiated responsibility' and 'equity' as fair

\footnotetext{
${ }^{15}$ Thomas M. Franck, Fairness in International Law and Institutions, Ibid 79.

${ }^{16}$ ibid 26.

${ }^{17}$ Thomas M. Franck, The Power of Legitimacy Among Nations (Oxford University Press 1990) 52.

${ }^{18}$ ibid 90-95.

${ }^{19}$ ibid 150-153.

${ }^{20}$ ibid 184.

${ }^{21}$ Franck (n 14) 384.

22 ibid 381.
} 
principles, he has ignored the role of 'polluter pays principle', a widely acknowledged principle of liability in the domestic legal systems of developed countries, as a fair principle of distributing burdens of remedying such problems. ${ }^{23}$ However, he suggests that substantial reduction in the rate of emissions of ozone depleting substances supports his case that fair agreements are more likely to be complied with. ${ }^{24}$

Franck's both components of fairness are important to encourage compliance with international law. However, his four factors are not easy to define in any objective way and provide little guidance for determining how to aggregate the four factors into a single judgement about legitimacy. ${ }^{25}$ Moreover, Franck is not sure that 'legitimacy' is truly the determinant of compliance pull because states would like to violate a rule if it is unjust although legitimate. ${ }^{26}$ However, Gerry J. Simpson suggests that it is impossible to reconcile procedural and distributive justice. ${ }^{27}$

Franck argues that states comply with international rules not primarily because they have consented rather because they are member of international community. According to him, a treaty to commit genocide would be invalid as it is inconsistent with community's basic public policy that is community's ultimate peremptory norms. ${ }^{28}$ Although the Convention on the Prevention and Punishment of the Crime of Genocide was adopted in 1948 to prevent the participating countries from committing genocide in war and peacetime, the norm not to commit genocide is considered as norm of customary international law, and therefore prohibits all states whether or not they have ratified the Genocide Convention.

Although sanctions or coercive enforcement is not a prominent feature of Franck's theory, he does not explicitly rule out sanctions as an effective mechanism to secure compliance in some areas of international law. For example, he notes that sanctions may have had some effect in causing Rhodesia and South Africa to comply with international mandates. ${ }^{29}$

\section{Transnational Legal Process}

Transnational legal process, according to Harold Hongju Koh, professor of international law at Yale Law School, is 'the process whereby an international law

\footnotetext{
${ }^{23}$ ibid 380-393.

24 ibid.

${ }^{25}$ Setear (n 4) 171-172.

${ }^{26}$ Franck (n 18) 238.

${ }^{27}$ Gerry J. Simpson, 'Is International Law Fair?' (1996) 17 Michigan Journal of International Law 615, 626.

${ }^{28}$ Thomas M. Franck, 'Legitimacy in the International System' (1988) 82(4) American Journal of International Law 705.

${ }^{29}$ ibid 290.
} 
rule is interpreted through the interaction of transnational actors in a variety of lawdeclaring fora, then internalised into a nation's domestic legal system' ${ }^{30}$

Transnational legal process has four distinctive features. First, it is non-traditional in the sense that it breaks down two traditional dichotomies between domestic and international, public and private. Second, it is non-statist in the sense that the actors in this process are not just, or even primarily, nation-states, but include non-state actors as well. Third, the process is dynamic, not static. Transnational law transforms, mutates, and percolates up and down, from public to the private, from the domestic to the international level and back down again. Fourth and finally, it is normative. From the interaction of actors in the transnational legal process, new rules of law emerge, which are interpreted, internalised, and enforced, thus beginning the process all over gain. The concept embraces not just the descriptive workings of a process, but the normativity of that process. It focuses not simply upon how interaction among actors shapes law, but also on how law shapes and guides future interactions, in short, how law influences why nations obey international law. ${ }^{31}$

In order to explain these four features of transnational legal process, Koh cites Iranian Hostages crisis. In the late 1960s, a California engineering firm called Dames $\&$ Moore signed a contract to conduct a nuclear power plant site study with the Atomic Energy Organisation of Iran. The agreement was negotiated against a 'public' backdrop not just of Iranian and United States domestic law, but of numerous bilateral and multilateral treaty commitments between the Iranian and United States governments. In 1979, the ouster of Shah and the seizure of 52 American hostages triggered a surge of emergency host and home-country regulations that dramatically affected these pre-existing private deals. The Atomic Energy Organisation cancelled the contract, upon which Dames \& Moore sued Iran and its instrumentalities in United States district court. When the court vacated Dames \& Moore's judicial attachment of Iranian bank property based on the 1981 executive orders implementing the US-Iran executive agreement that freed the hostages, Dames \& Moore filed a new district court complaint against the US seeking to enjoin enforcement of those executive orders. The suit ultimately resulted in a historic loss in the United States Supreme Court and Dames \& Moore proceeded to the IranUnited States Claims Tribunal. But the Tribunal excluded it from its jurisdiction depending on an Iranian forum-selection clause in the original contract. ${ }^{32}$

Koh observes that the Iranian Hostages crisis illustrates each of the four features of transnational legal process mentioned above. First, it does not fit traditional categories. It cannot be neatly cabined within 'domestic law' traditionally regarded as

\footnotetext{
${ }^{30}$ Harold H Koh, 'Bringing International Law Home' (1998) 35 Houston Law Review 623, 626.

${ }^{31}$ Harold H Koh, 'Transnational Legal Process' (1996) 75 Nebraska Law Review181, 184.

32 ibid 184-185.
} 
governing conduct within borders, or 'international law' which governs conduct across borders. Nor can it be characterised as 'public' international law, the law among nation-states, which encompasses what national do to or with each other or 'private international law, classically regarded as cross-border among non-state actors. Second, the key actors in this process include not only nation states, but also non-state actors such as the International Monetary Fund, various multinational enterprises (large banks freezing and transferring the assets), and the individual hostages.

Third, the process was dynamic, not static. A contract which was initially a private business deal between a US multinational and an organisation of Iranian government dissolved into a domestic legal dispute, then percolated upward into a public international dispute which was ultimately resolved by the US and Iranian governments by an agreement on the basis of public international and domestic public law. However, this triggered both domestic constitutional claims by a multinational corporation against its own government in its own domestic courts and international expropriation and breach of contract claims against a foreign government in a newly constituted international tribunal. Fourth, the interactions among these transnational players not only generated law (the domestic private law of letters of credit, the domestic public law of executive power, the international private law of dispute-resolution, and the public international law of diplomatic relations law) but generated new interpretations of those rules and internalised them into domestic law that now guides and channels those actors' future conduct. ${ }^{33}$

Transnational legal process is, according to Koh, normative, dynamic, and constitutive. The transaction generates a legal rule which will guide future transnational interactions between the parties; future transactions will further internalise those norms; and eventually, repeated participation in the process will help to reconstitute the interests and even the identities of the participants in the process. ${ }^{34}$ Koh cites the ABM Treaty Reinterpretation Debate to demonstrate how the world's most powerful nation, the United States, returned to compliance with international law. In 1972 the United States and the former U.S.S.R. signed the bilateral AntiBallistic Missile Treaty (ABM Treaty), which expressly banned the development of space-based systems for the territorial defense of the USA. Thirteen years later, in October 1985, the Reagan Administration proposed the Strategic Defense Initiative (SDI), popularly called 'Star Wars' in violation of the above Treaty.

The Reagan Administration proposed to reinterpret the plain language of the treaty to permit SDI without the consent of either the Senate or the Soviet Union. The controversy raged in many fora. Transnational legal actors such as a U.S. Senator

\footnotetext{
${ }^{33}$ ibid 185-186.

${ }^{34}$ Koh (n 15) 2646.
} 
(Sam Nunn), a private 'norm entrepreneur' (Gerard Smith), and several nongovernmental organisations (the Arms Control Association and the National Committee to Save the ABM Treaty) formed an 'epistemic community' to address the legal issue. That community provoked a series of interactions with the U.S. government and challenged the Administration's new interpretation in both public and private settings, and succeeded in internalising the narrow interpretation into several legislative products. The executive branch responded by internalising that interpretation into its own official policy statement. ${ }^{35}$

According to Kho, actors obey international law as a result of repeated interaction with other governmental and nongovernmental actors in the international system. A state's violation of international law creates inevitable frictions that hinder its ongoing participation within the transnational legal process. For example, when US engaged in governmental kidnapping of Mexican citizens that activity impaired its ability to negotiate the North American Free Trade Agreement with the Mexican government. Similarly, when a developing nation defaults on a sovereign debt, that activity impairs its ability to secure new lending. When the US denies the jurisdiction of ICJ as a defendant, that decision impairs its ability to invoke the Court's jurisdiction as a plaintiff. ${ }^{36}$ To avoid such frictions in a nation's continuing interactions, national leaders may shift over time from a policy of violation of international law to one of compliance. Through interaction actors create patterns of behaviour and generate norms of external conduct which they in turn internalise. States that abide by laws internalise international law by incorporating it into their domestic legal and political structures, through executive sanction, legislation, and judicial decisions which take account of and incorporate international norms. ${ }^{37}$ As nations participate in the transnational legal process, through a complex combination of rational self-interest, transnational interaction, norm-internalisation, and identity formation, international law becomes a factor driving their international relations. ${ }^{38}$

\section{Reputational Theory}

Andrew T. Guzman, professor of law at Berkeley School of Law, University of California, has developed the reputational theory of compliance. The theory assumes that states are rational and act in their own self-interest. ${ }^{39}$ The decision to honour or breach a promise made to another state imposes costs and benefits upon a country and its decision makers. The theory assumes that decision makers behave in such a

\footnotetext{
${ }^{35}$ ibid 2648.

${ }^{36}$ See, e.g., Nicaragua's suit against the United States, Military and Paramilitary Activities, Nicaragua v. US [1986] ICJ Report 14.

37 ibid 204.

${ }^{38}$ ibid 205.

${ }^{39}$ See, Andrew T. Guzman, 'International Law: A Compliance Based Theory' (2001) UC Berkeley School of Law Public Law and Legal Theory Working Paper 47, 18.
} 
way as to maximize the payoffs that result from their actions. Where the benefits of breach outweigh its costs, we expect a country to violate international law. ${ }^{40}$ International law succeeds when it alters the payoffs in such a way as to get compliance with international law when, in the absence of such law, states would behave differently. In other words, international law succeeds when promises made by states generate some compliance pull. ${ }^{41}$

In a prisoner's dilemma game defection is the dominant strategy for each party and no cooperation will be achieved and that international law will be irrelevant. However, the prisoner's dilemma can be solved by establishing an enforceable agreement with a penalty clause for non-cooperation in a way that the penalty will change the payoffs enough to make cooperation a dominant strategy for each party. According to Guzman, to generate a model in which international law matters, it is, then, necessary to identify a mechanism through which violations are sanctioned in some fashion. Sanction, to him, encompasses more than just direct punishments resulting from a failure to live up to one's international obligations. It includes all costs associated with such a failure, including the punishment or retaliation by other states and reputational costs that affect a state's ability to make commitments in the future. $^{42}$

He models international obligation as a two-stage game. In the first stage, states negotiate over the content of the law and the level of commitment. In the second stage, states decide whether or not to comply with their international obligations. A state's compliance decision is made on an assessment of its self-interest. This selfinterest can be affected by international law in two ways. First, it can lead to imposition of direct sanctions such as trade, military, or diplomatic sanctions. Second, it can lead to reputational capital in the international arena. If the direct and reputational costs of violating international law are outweighed by the benefits thereof a state will violate that law otherwise it will comply. ${ }^{43}$ Guzman notes that optimal compliance with international law is more likely if states face direct sanctions for such violations. This is because reputational sanctions are generally, though not always, weaker than an optimal sanction. ${ }^{44}$

If a party violates international law it will affect its reputation and will have negative effect in future interactions with other party. Although a reputational damage impacts country incentives, in some instances that impact will be insufficient to alter country's behaviour. Thus the model does not merely explain why nations comply with international law despite the weakness of existing enforcement

\footnotetext{
${ }^{40}$ ibid 40.

${ }^{41}$ ibid.

${ }^{42}$ Guzman (n 40) 18-22.

43 ibid 24.

${ }^{44}$ ibid 46.
} 
mechanism. It also explains why they sometimes choose to violate the international law. The theory thus reconciles the claim that international law affects behaviour with the fact that the law is not always followed. ${ }^{45}$

According to Guzman, when states cooperate in order to resolve straightforward coordination games, international law has a limited role to play. Where two neighbouring countries wish to shut down an international organize crime syndicate, cannot alone succeed without joint effort, enter into an agreement in which each promises to pursue the syndicate. As cooperation is the dominant strategy for each country, neither country has an incentive to violate its commitment. No threat of sanction is needed to achieve cooperation. Even the form of the agreement is not terribly important. An informal agreement could be equally effective. ${ }^{46}$

Although the punitive sanctions have the potential to be used as optimal sanctions, they are not generally imposed by neutral third parties but rather by injured states. Therefore, there is the risk that the sanctions will be excessive. Despite their shortcomings, according to Guzman, the relevance of punitive sanctions should not be dismissed too quickly. In some situation punitive sanctions may provide efficient incentives to states to comply with international law. In infinitely repeated games, where states interact repeatedly overtime, it may be worthwhile for states to develop reputations for punishing offenders. By punishing offenders today, states increase the likelihood of compliance tomorrow. ${ }^{47}$

Guzman views that all else equal, it is reasonable to expect that the compliance pull of international law will be the weakest when the stakes at issue are large. This is because the reputational effects have limited power. The likelihood that reputational effects are sufficient to ensure compliance grows smaller as the stakes grow larger. Reputation plays a more important role when the costs and benefits of a particular action are small ${ }^{48}$.

The theory predicts that international law will have the smallest impact in those areas of greatest importance to countries such as laws of war, territorial limits, arms agreements, and military alliance. These areas are least likely to be affected by international law. ${ }^{49}$ It suggests that many of the most central topics in traditional international law scholarship are the most resistant to influence. According to him, rather than concentrating on those topics that are of greatest importance to states, international law scholars may be better off to devote more attention to those areas in which international law can yield the greatest benefits. The most promising fields of

\footnotetext{
${ }^{45}$ ibid 26.

46 ibid 36-37.

${ }^{47}$ ibid 48 .

${ }^{48}$ ibid 49-53.

${ }^{49}$ ibid 68-71.
} 
study, therefore, are those in which reputational effects are likely to affect behaviour. These include for example, the entire range of international economic issues, from trade to the international regulation of competition law to environmental regulation ${ }^{50}$.

\section{Comparative Assessment of the Theories of Compliance}

It appears from the above discussion that the theories provide different explanations regarding why nations comply with international law. These explanations are sometimes similar, complementary or even contradictory to one another. In the following paragraphs an attempt has been made to assess the major arguments of the theories of compliance from a comparative perspective.

Broadly the theories examined above shows a preference between management or enforcement approach. According to the Chayeses, proponents of the managerial school, there is a general propensity of states to comply. Three factors, efficiency, interests and norms contribute to this general propensity of compliance. Since noncompliance is not wilful in most cases, they argue that a coercive enforcement model for ensuring compliance is inappropriate. According to them, management tools such as reporting, transparency, verification, monitoring, dispute resolution, capacity building encourage compliance. They ask why focus on coercion and punishments when the major concern is not wilful disobedience rather factors such as ambiguity and insufficient capacity.

Although Frank does not explicitly rule out the importance of sanction in improving the compliance behaviour in some areas of international law, he argues that fairness will motivate toward compliance. Koh, on the other hand, argues that nations obey international law because the norms are internalised into domestic normative system, therefore, enforcement through coercive measure is not an issue. Rather he argues that we should seek to acquire a greater understanding of the transnational legal process. Reputational theory, applying classical prisoner dilemma game, however, argues that where defection is the dominant strategy, direct sanction or reputational costs can influence states toward compliance. Guzman argues that when the costs of sanctions outweigh benefits of defection, nations will obey international law.

Franck's fairness theory emphasizes on the normative aspect of international law. $\mathrm{He}$ argues that states obey international law because they believe they ought to. Chayeses managerial school also emphasizes the normative element of law. According to them, people often follow law out of a sense of duty and obligation even without calculating the possibility of punishment. They view that on the international level pacta sunt servanda meaning treaties must be observed by their

${ }^{50} \mathrm{ibid}$. 
parties in good faith, has compliance pull. Reputational theory also argues that where stakes are high, international law has little influence on state's compliance behaviour.

The role of fairness or legitimacy has been debated. Franck argues that if a law is fair it will encourage compliance. As the Vienna Ozone Convention and the Montreal Protocol contain fair provisions, he suggests that the evidence of substantial reduction of ozone depleting substances prove that fair agreements are more likely to be complied with. Koh argues that in order to find out why nations obey international law, one has to understand the role of transnational legal process. According to him, both the managerial theory and the fairness theory emphasize voluntary obedience. Neither Franck nor Chayeses explain how norms are internalized. Koh suggests that transnational legal process provides the missing link. According to Koh it is the transnational legal process that motivates states toward compliance. The process starts with an interaction provoked by one or more transnational actors. The international law is then interpreted and internalized into the domestic normative systems of the parties.

Another importance of the Koh's theory is that it highlights the role of various state and non-state actors at the domestic, regional and international level. They play key role in motivating states toward compliance. Reputational theory undermines the role of non-state actors in the international legal system.

Finally, managerial school argues that in the interdependent world, the need to belong to the community of states encourages compliance with international norms and therein lies the Chayeses' New Sovereignty. They observe that connection to the rest of the world and the political ability to be an actor within it are more important than any tangible benefits in explaining compliance with international regulatory agreements. Similarly, Koh views that the impetus of compliance is not so much a nation's fear of sanction, as it is fear of diminution of status through loss of reputation. Guzman's reputational theory appear to make similar claim that part of the answer to the compliance question is that states comply with international law to avoid a bad reputation on the world stage.

\section{Conclusion}

The major theories on compliance with international law by states, as examined above, appear to highlight different aspects of compliance process from their respective perspectives. They inform us how different factors such as, managerial techniques, notions of fairness, legitimacy or even sense of reputation can significantly influence the compliance behaviour of states with regard to international law obligations. Indeed a deeper understanding of these theories can help us improve existing compliance behaviour of states as well as design better compliance mechanisms to meet the future challenges of international community. 
While some theories emphasize the role of managerial techniques, others underscore the need for enforcement mechanisms in improving compliance behaviour of states. Where the obligations are complex and require states to change socioeconomic policies at deeper level over a long period of time and the issue is capacity building, perhaps managerial approach is better. For example, global environmental problems of ozone depletion, climate change, biodiversity loss etc. But in cases of violation of human rights, humanitarian rights, or arms control, where compliance is more a matter of will of the state authority, enforcement could be a good option. A compliance mechanism could also employ both managerial and enforcement techniques at the same time or it can employ different approaches at different levels of performance, depending on the objectives it wants to achieve. Montreal Protocol 1987 while uses managerial techniques to improve the compliance behaviour of developing countries, mandates at the same time for punishment measures for defecting states. For example, ban on the export and import of ozone depleting substances on states which stay out-side the regime of the Protocol but still want to reap the benefit of free-riding. The 'carrot and stick approaches'-considered to have played a significant role in the success of the Protocol. 